\title{
Uptake and Phosphorylation of 2-Deoxy-D-Glucose by Normal Human Uterine Muscles and Uterine Myomata
}

Previous investigation by $\mathrm{us}^{1}$ disclosed that human uterine myomata do not develop significant tension in excess potassium and also respond poorly to autonomic and other drugs when compared to normal uterine muscles. A search into the reason for this unresponsiveness is being carried out based on the speculation that the energy for maintenance of a polarized cell membrane is lacking in myomata. Uptake and phosphorylation of 2-deoxy-D-glucose (DOG) was thus studied because glucose is the primary substrate for energy production in normal uterine muscles.

Materials and methods. Tissues were obtained from 20 premenopausal patients. Uterine muscles from 10 patients were adjudged to be normal by criteria described previously ${ }^{2}$. Myomata were obtained from 10 other patients. These tissues were used not later than $18 \mathrm{~h}$ after surgery. When necessary, they were stored in Ringer-Locke U.S.P. XIV solution at $4{ }^{\circ} \mathrm{C}$. Later, working sections of approximately $1 \mathrm{~mm}$ thickness and $150 \mathrm{mg}$ were cut from each tissue and used as follows: 2 sections for analysis of DOG and DOG phosphate, 3 sections for analysis of inulin (extracellular space), 1 section for estimation of endogenous inuloid material, 1 section for estimation of total tissue water. These sections were incubated for $2 \mathrm{~h}$ in gassed $\left(95 \% \mathrm{O}_{2}+5 \% \mathrm{CO}_{2}\right)$ Ringer-Locke U.S.P. XIV and heated to $37^{\circ} \mathrm{C}$. Inulin was measured by the method of RoE et al. ${ }^{3}$, DOG and DOG phosphate were determined as described by KIPNIS and CORI ${ }^{4}$ and WARAVDEKar and SASLAW ${ }^{5}$. The intracellular concentrations of sugar and phosphate were calculated from the formula of KIPNIS and PARRISH ${ }^{6}$. The total tissue water was obtained by subtraction, using the wet weight and the weight after drying at $120^{\circ} \mathrm{C}$ to constant weight.

Results. Both types of tissue were incubated in a solution containing $0.82 \mathrm{mg} / \mathrm{ml}$ of DOG and this led to an intracellular concentration of DOG plus DOG phosphate of approximately $1 \mathrm{mg} / \mathrm{ml}$ in each tissue. The intraccllular DOG phosphate in myomata was however significantly lower than in normal muscles. Incubation also resulted in a net water loss in each tissue. Inulin space in myomata was significantly greater than in normal muscles.

Discussion. The response to some autonomic drugs can be related to their affect on the resting membrane potential of the responding cells ${ }^{7}$. The maintenance of the membrane potential in smooth muscle cells is believed dependent on active transport progresses for inward movement of potassium and extrusion of intracellular sodium and both processes have been coupled with uptake

Uptake and phosphorylation of 2-deoxy-D-glucose by normal human uterine muscles and uterine myomata.

Parameter

Total water $\left(\mathrm{cm}^{3} / \mathrm{kg}\right)$

Inulin space $\left(\mathrm{cm}^{3} / \mathrm{kg}\right)$

Water loss $\left(\mathrm{cm}^{3} / \mathrm{kg}\right)$

Intracellular DOG $(\mathrm{mg} / \mathrm{ml})$

Intracellular DOGP (mg/ml)

Extracellular DOG (mg/kg)

Myomata

Normal muscles

DOG is 2-deoxy-D-glucose. DOGP is 2-deoxy-n-glucose phosphate. $\checkmark$ Value is a mean of 10 experiments $t$ its standard error. $b$ Indicates value for myomata differs from normal muscles $P=0.05$ or less. and utilization of glucose ${ }^{7}$. The present experiments demonstrate that human uterine myomata, though able to take up DOG intracellularly, cannot phosphorylate DOG as completely as can normal uterine muscles. Because $D O G$ is phosphorylated by hexokinase as is glucose ${ }^{8}$ and is thought to be transported by the same system responsible for glucose transport ${ }^{9}$, our observations on phosphorylation of DOG should apply to glucose as well. We therefore believe that such reduced phosphorylation of glucose is related to the poor contractile response of myomata to some drugs and depolarizing solutions which caused good responses in normal muscles ${ }^{1}$. We are mindful that these experiments were performed on cut muscles and that permeability to many substances including $D O G$ increases in cut muscles compared to intact ones ${ }^{10}$. However the intracellular total DOG (DOG + DOG phosphate) was the same in both tissues and was higher than extracellular DOG indicating active transport. Thus it would seem that phosphorylation rather than active transport of glucose is defective in myomata.

The inulin space in our normal muscles was $233 \mathrm{~cm}^{3} / \mathrm{kg}$. It compares favorably with values for guinea-pig ${ }^{11}$ and rabbit $^{12}$ uterus. The inulin space for myomata is 319 $\mathrm{cm}^{3} / \mathrm{kg}$ and is significantly greater than in normal muscles. We cannot explain this difference but suggest that sectioning of myomata results in more cut muscle cells owing to their non-symetrical orientation ${ }^{\mathbf{1 3}}$.

Zusammenfassung. Ein Vergleich der aktiven Aufnahme und Phosphorylierung von 2-deoxy-D-glucose im normalen Uterusmuskel und im Myomata des Menschen zeigte, dass beide Gewebe den Zucker unter Energieaufwand aufnehmen. Myomata hingegen phosphoryliert weniger aufgenommenen Zucker als der normale Uterusmuskel.

\section{E. GoldBerG ${ }^{14}$ and I. Rosenblum}

Department of Pharmacology, Albany Medical College, Albany (New York 12208, USA),

9 February 1968.

1 I. Rosenblum and A. A. Stein, J. Pharmac. exp. Ther. 146, 313 (1964).

2 1. Rosenblum and A. A. Stern, J. Pharmac exp. Ther. 144, 138 (1964).

3 J. H. Roe, J. H. Erstein and N. P. Goldstein, J. biol. Chem. 178,839 (1949).

4 D. M. Kirnis and C. F. Cori, J. biol. Chem. 234, 171 (1959).

5 V. S. WARA YDEkAR and L. D. SaSLAW, J. biol. Chem. 234, 1945 (1959).

- D. M. Kupnis and J. E. Parkish, Fedn Proc. Fedn Am. Socs exp. Biol. 24, 1051 (1965).

${ }^{7}$ G. Burnstock, M. E. Holman and C. L. Prosser, Physiol. Rev. 43,482 (1963).

* F. A. Riddick jR., D. M. Reister and D. M. Kipnis, Diabetes 11, $171(1962)$.

- F. C. Batraglia and P. J. Randle, Biochem. J. 75, 408 (1960).

10 D. M. Kipnis, Ann. N.Y. Acad. Sci. 82, 354 (1959).

11 J. Farrant, J. Physiol. 778, 1 (1965).

12 E. E. Daniel and B. N. Dantel, Can. J. Biochem. Physiol. 35 1205 (1957).

13 Supported by grant No, GM-11,600 U.S.P.H.S.

14 Present address: Department of Obstetrics and Gynecology, The Johns Hopkins University School of Medicine, Baltimore, Maryland. 